\title{
RANCANG BANGUN SIMULASI EDUKASI TATA CARA SHOLAT 5 WAKTU DAN PENGENALAN HURUF HIJAIYAH BERBASIS VIRTUAL REALITY (VR)
}

\author{
Dayat $^{1}$, I Made Widiarta ${ }^{2}$, Fahri $^{3}$ \\ 1.2 Program Studi Informatika, Fakultas Teknik, Universitas Teknologi Sumbawa \\ 1.2 Jl. Raya Olat Maras Batu Alang-Sumbawa Besar

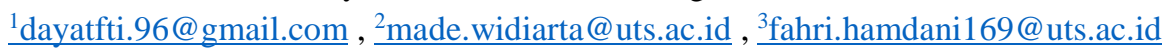

\begin{abstract}
Abstraksi
Penelitian ini bertujuan unuk merancang dan membangun Game Edukasi Tata Cara Sholat 5 Waktu dan Pengenalan Huruf Hijaiyah Berbasis Virtual Reality (VR) agar dapat dimanfaatkan oleh guru mata pelajaran pendidikan agama Islam dalam melakukan proses belajar mengajar. Adapun metode penelitian yang digunakan yaitu metode kualitatif yang bersifat deskriptif dan metode pengumpulaln data yang digunakan dalam penelitian ini yaitu metode observasi, wawancara, dokumentasi, dan studi pustaka serta menggunakan metode Prototype sebagai metode pengembangan perangkat lunak. Game Edukasi Tata Cara Sholat 5 Waktu dan Pengenalan Huruf Hijaiyah Berbasis Virtual Reality (VR) ini dibangun menggunakan bahasa pemrograman C\# dan Photoshop, Blender untuk membuat desain gambar 3 dimensi (3D). Dalam Game Edukasi Tata Cara Sholat 5 Waktu dan Pengenalan Huruf Hijaiyah Berbasis Virtual Reality (VR) nantinya guru mata pelajaran pendidikan agama Islam memiliki wewenang untuk menggunakan metode ini untuk melakukan proses belajar mengajar yang efektif.
\end{abstract}

Kata Kunci : Game, Edukasi, Sholat 5 Waktu dan Pengenalan Huruf Hijaiyah, Virtual Reality (VR), Prototype, C\#.

\begin{abstract}
This research aims to design and build educational games called Prayer procedure 5 times and recognition ofHijaiyah letters based on Virtual Reality (VR) to be used by teachers of Islamic religious subjects in teaching and learning process. The research method is Qualitative descriptive methods. Collecting the data used in this research are observation, Interviews, documentation, library studies and using the Prototype method as a software development method. Prayer Educational Games 5 times and recognition of Hyjaiyah letters-based on Virtual Reality (VR) is built Using C\# and Photoshop programming , and blender to create 3-dimensional image design (3D). By using The 5 Times Prayer Ordinance Education Game and introduction of Hijaiyah letters based Virtual Reality $(V R)$ the teacher of Islamic Religious lessons have the authority to use This method to perform an effective teaching learning process.
\end{abstract}

Keywords : Games, Education, Praying 5 Times and Introduction to Hijaiyah Letters, Virtual Reality (VR), C\#. 


\section{PENDAHULUAN}

\subsection{Latar Belakang}

Sekolah merupakan madrasah bagi anak-anak untuk belajar menuntut ilmu. Sekolah yang baik adalah sekolah yang menghasilkan lulusan terbaik, baik dari segi prestasi akademik maupun ahlak dan kepribadian anak. Metode-metode pengajaran dan penyampaian materi yang tepat dapat membuat anakanak lebih cepat dan tanggap dalam memahami materi yang disampaikan. Berangkat dari hal tersebut faktor lingkungan kelas adalah hal yang paling utama dalam mendukung anak dalam memahami materi yang disampaikan di kelas. Mata pelajaran yang membutuhkan ketenangan dan kenyamanan adalah pendidikan agama Islam. Karena hal tersebut dapat menigkatkan pemahaman anak dalam memahami materi terutama dalam hal praktik.

Pendidikan agama Islam merupakan mata pelajaran yang wajib ada disetiap sekolah untuk membentuk ahlak dan kepribadian anak. Pembentukan ahlak atau kepribadian seorang anak dapat dilakukan dengan metode-metode yang tepat. Salah satunya adalah menggunakan metode pegajaran dan penyampaian materi yang mudah dipahami oleh anakanak. Namun yang terjadi saat ini adalah metode pangajaran yang kurang tepat dapat menurunkan semangat belajar anak-anak. Penulis melakukan observasi di SMP Negeri 2 Moyo Hulu, kondisi yang terjadi pada saat jam pelajaran pendidikan agama.

Berdasarkan masalah diatas maka penulis akan membuat suatu metode pembelajaran berbasis game yaitu Game Edukasi Tata Cara Sholat 5 Waktu dan Penggenalan Huruf Hijaiyah Berbasis Virtual Reality yang mampu mengedukasi anak-anak dalam belajar agama. Game ini dimainkan dengan menggunakan perangkat kacamata virtual atau VR Headset yang mendukung audio dan video grafis. Ketika anak-anak memainkan game ini mampu membuat pengguna seolah-olah sedang berada didunia nyata. Sehingga dapat mengurangi gangguan dari luar.

Diharapkan dengan adanya game ini, dapat mempermudah dalam mempelajari materi tata cara sholat 5 waktu dan pengenalan huruf hijaiyah.

\subsection{Rumusan Masalah}

Berdasarkan latar belakang yang dijelaskan diatas, maka permasalahan yang dibahas adalah "Bagaimana Membuat Game Edukasi Tata Cara Sholat 5 Waktu dan Pengenalan Huruf Hijiayah di SMP Negeri 2 Moyo Hulu Sebagai Media Pembelajaran yang Efektif'.
Adapun tujuan dari penelitian ini adalah membuat metode pembelajaran berbasis game yang dapat megedukasi anak-anak SMP Negeri 2 Moyo Hulu dalam hal belajar agama.

\subsection{Batasan Masalah}

Adapun ruang lingkup masalah dari Game Edukasi Tata Cara Sholat 5 Waktu dan Pengenalan Huruf Hijaiyah adalah sebagai berikut :

a. Penelitian dilakukan di SMP Negeri 2 Moyo Hulu.

b. Sumber data pada penelitian diperoleh dari guru mata pelajaran pendidikan agama islam kelas VII di SMP Negeri 2 Moyo Hulu.

c. Aplikasi yang dibuat yaitu aplikasi edukasi tata cara sholat 5 waktu dan pengenalan huruf hijaiyah berbasis game.

d. Game yang dibuat hanya berjalan di platform android versi 5.1 (Lollipop).

e. Game yang dibuat hanya bisa dimainkan dengan menggunakan kacamata virtual atau Virtual Reality Headset.

f. Belum adanya aplikasi edukasi tata cara sholat 5 waktu dan pengenalan huruf hijaiyah berbasis game di SMP Negeri 2 Moyo Hulu.

\subsection{Tujuan Penelitian}

Adapun tujuan dari penelitian ini adalah membuat metode pembelajaran berbasis game yang dapat megedukasi anak-anak SMP Negeri 2 Moyo Hulu dalam hal belajar agama.

\subsection{Manfaat Penelitian}

Adapun manfaat dari penelitian ini di buat berdasarkan dari penelitian yang akan dilakukan adalah sebagai berikut:

\subsubsection{Manfaat Bagi Penulis Selanjutnya}

Adapun manfaat bagi penulis selanjutnya dalam penelitian ini adalah sebagai berikut:

1. Untuk mengimplementasikan secara langsung dan meningkatkan ilmuilmu yang telah didapatkan selama perkuliahan.

2. Untuk mengetahui kondisi dan masalah sebenarnya yang terjadi di dunia kerja serta membandingkan teori-teori yang ada dengan masalah yang sebenarnya.

3. Untuk memperkenalkan gambaran umum perusahaan yang diperlukan mahasiswa dalam memasuki dunia kerja yang sesuai dengan bidangnya dan sebagai pengalaman kerja. 
4. Menambah kepercayaan diri dan keberanian serta tanggung jawab dalam melaksanakan tugas yang dipercayakan oleh instansi atau perusahaan kepada mahasiswa.

1.5.2 Manfaat Bagi SMP Negeri 2 Moyo Hulu Adapun manfaat bagi SMPN 2 Moyo Hulu dalam penelitian ini adalah sebagai berikut:

1. Memudahkan pengajar atau guru dalam menyampaikan materi mata pelajaran agama islam.

2. Memudahkan siswa SMPN 2 Moyo Hulu dalam mempelajari tata cara sholat 5 waktu dan pengenalan huruf hijaiyah.

\subsubsection{Manfaat Bagi Universitas}

Adapun manfaat bagi Universitas dalam penelitian ini adalah sebagai berikut:

1. Mengetahui kemampuan mahasiswa dalam menguasai materi pelajaran yang diperoleh dibangku kuliah dalam menerapkan ilmunya dan sebagai bahan evaluasi.

2. Memberikan gambaran tentang kesiapan mahasiswa dalam menghadapi dunia kerja yang sebenarnya.

3. Dapat meningkatkan kualitas lulusannya melalui pengalaman kerja.

4. Dapat dikenal di dunia industri sebagai universitas dengan mahasiswa kompeten dengan praktiknya dilapangan.

\section{LANDASAN TEORI}

\subsection{Tinjauan Pustaka}

Pada penelitian ini penulis mempunyai beberapa referensi terkait judul Game Edukasi Tata Cara Sholat 5 Waktu dan Pengenalan Huruf Hijaiyah yaitu jurnal penerbit (Mila Jumarlis, 2018) yang berjudul "Aplikasi Pembelajaran Smart Hijaiyah Berbasis Augmented Reality". Didalam jurnal tersebut dijelaskan bahwa pembelajaran Smart Hijaiyah akan menampilkan penjelasan huruf Hijaiyah, diantaranya adalah informasi huruf Hijaiyah dalam hal Makhrajnya, cara penulisan huruf hijaiyah dan suara huruf hijaiyah dengan pemanfaatan teknologi Augmented Reality dengan menggunakan marker.
Perbedaan dengan penelitian yang penulis lakukan adalah basis aplikasi yang dibangun, materi yang disampaikan dan penggunaan teknologi. Pada Game Edukasi Tata Cara Sholat 5 Waktu dan Pengenalan Huruf Hijaiyah terdapat dua materi yaitu tata cara sholat 5 waktu dan pengenalan huruf hijaiyah yang berbasis Virtual Reality.

Jurnal yang berjudul "Game Edukasi Penjelajah Berbasis Virtual Reality" yang diterbitkan oleh Robby Wijaya Koerniawan 2018 menjelaskan tentang game dengan topik penjelajah sedangkan pada Game Edukasi Tata Cara Sholat 5 Waktu dan Pengenalan Huruf Hijaiyah berbasis virtual reality membahas dua topik yaitu materi tata cara sholat 5 waktu dan pengenalan huruf hijaiyah berbasis virtual reality.

Jurnal yang berjudul "Rancang Bangun Aplikasi Edugame Selamatkan Hutan Indonesia Berbasis Unity 3D”yang diterbitkan oleh Sudarwanto 2018 menjelaskan tentang game dengan topik pembelajaran yang mengedukasi siswa dalam menyelamatkan hutan menggunakan Unity 3D. Sedangkan pada Game Edukasi Tata Cara Sholat 5 Waktu dan Pengenalan Huruf Hijaiyah berbasis virtual reality membahas dua topik yaitu materi tata cara sholat 5 waktu dan pengenalan huruf hijaiyah berbasis virtual reality 3 dimensi.

Penelitian yang berjudul "Efektifitas Media Game Edukasi Untuk Meningkatkan Kemampuan Kosakata Bahasa Bahasa Jepang" penelitian ini menjelaskan bahwa media game edukasi (matching game) efektif untuk meningkatkan kemampuan kosakata bahasa jepang.

\subsection{Dasar Teori}

Dalam pembuatan Game Edukasi Tata Cara Sholat 5 Waktu dan Pengenalan Huruf Hijaiyah Berbasis Virtual Reality (VR), penulis menggunakan beberapa literatur mengenai game yang dibangun berdasarkan sumber-sumber terpercaya untuk menjadi acuan dan rujukan sebagai pendukung dari project yang dibuat.

\subsubsection{Definisi Rancang Bangun}

Rancang merupakan serangkaian prosedur untuk menerjemahkan hasil analisis dari sebuah sistem kedalam bahasa pemrograman untuk mendeskripsikan dengan detail bagaimana komponen-komponen sistem diimplementasikan. Sedangkan pengertian bangun atau pembangunan sistem adalah kegiatan mencipatakan baru maupun mengganti atau memperbaiki sistem yang telah ada baik secara keseluruhan maupun sebagian (Pressman, 2002). 
Rancang bangun sangat berkaitan dengan perancangan sistem yang merupakan satu kesatuan untuk merancang dan membangun sebuah aplikasi.

Perancangan sistem adalah penentuan proses dan data yang diperlukan oleh sistem baru. Jika sistem itu berbasis komputer, rancangan dapat menyertakan spesifikasi jenis peralatan yang akan digunakan (Tata Sutabri, 2005).

Perancangan sistem dapat didefinisikan sebagai gambaran, perencanaan, dan pembuatan sketsa atau pengaturan dari beberapa elemen yang terpisahkan kedalam satu kesatuan yang utuh dan berfungsi. Tujuan dari perancangan sistem yaitu untuk memenuhi kebutuhan para pemakai sistem dan memberikan gambaran yang jelas dan rancang bangun yang lengkap kepada programmer. Kedua tujuan ini lebih berfokus pada perancangan atau desain sistemyang terinci yaitu pembuatan rancang bangun yang jelas dan lengkap yang nantinya digunakan untuk pembuatan program komputernya (Jogiyanto, 2001).

Dari penjelasan diatas dapat disimpulkan rancang bangun sistem merupakan kegiatan menterjemahkan hasil analisa kedalam bentuk paket perangkat lunak kemudian menciptakan sistem tersebut atau memperbaiki sistem yang ada.

\subsubsection{Definisi Game}

Game berasal dari bahasa Inggris yang berarti permainan. Game (permainan) secara umum adalah sebuah aktivitas rekreasi dengan tujuan bersenang-senang, mengisi waktu luang, atau berolahraga ringan. Permainan biasanya dilakukan sendiri atau bersama-sama. Game merupakan aktifitas terstruktur atau semi terstruktur yang biasanya bertujuan untuk hiburan dan kadang dapat digunakan sebagai sarana pendidikan. Karakteristik game yang menyenangkan, memotivasi, membuat kecanduan dan kolaboratif membuat aktifitas ini digemari oleh banyak orang (Wahono, R.S 2009).

Dalam setiap game terdapat peraturan yang berbeda-beda untuk memulai permainannya sehingga membuat jenis game semakin bervariasi. Karena salah satu fungsi game juga sebagai penghilang stress atau rasa jenuh maka hamper setiap orang senang bermain game baik anak kecil, remaja maupun dewasa.

\subsubsection{Definisi Edukasi}

Edukasi atau disebut juga dengan pendidikan merupakan segala upaya yang direncanakan untuk mempengaruhi orang lain baik individu, kelompok, atau masyarakat sehingga mereka melakukan apa yang diharapkan oleh pelaku pendidikan. (Notoadmojo, 2003)

Edukasi merupakan proses belajar dari tidak tahu tentang nilai kesehatan menjadi tahu. (Suliha, 2002).

\subsubsection{Definisi Virtual Reality (VR)}

Virtual reality merupakan media desain yang efektif dan menguntungkan menggunakan aplikasi Virtual Reality dalam fase desain sistem struktur karena virtual reality memfasilitasi reinterpretasi dan evaluasi mendadak. Virtual reality juga memberikan kemudahan desainer untuk mengolah antara desain dengan struktur (Abdelhameed, 2013).

\subsubsection{Definisi SDLC (Software Development Life Cycle)}

Software Development Life Cycle (SDLC) atau sering disebut juga System Development Life Cycle adalah proses mengembangkan atau mengubah suatu sistem perangkat lunak dengan menggunakan modelmodel dan metodologi yang digunakan orang untuk mengembangkan sistem-sistem perangkat lunak sebelumya (berdasarkan best practice atau cara-cara yang sudah teruji baik). SDLC memiliki beberapa Model dalam penerapan tahapan prosesnya antara lain model waterfall, model prototype, model RAD, model iteratif, dan model spiral (Rossa A.S, 2016).

\section{METODOLOGI PENELITIAN}

\subsection{Metode Penelitian}

Metode yang digunakan dalam penelitian ini adalah penelitian deskriptif kualitatif yang dimana menurut Moleong (2016: 11) deskriptif kualitatif artinya mencatat dengan teliti berbagai fenomena yang dilihat dan didengar serta dibaca via wawancara atau catatan lapangan, foto, video tape, dokumentasi pribadi, catatan serta memo dan lain-lain. Peneliti harus membanding-bandingkan, mengkombinasikan, mengabstraksikan dan menarik kesimpulan. Dalam penelitian deskriptif kualitatif jenis data yang dikumpulkan berupa kata-kata, gambar dan bukan angka-angka. Hal ini dikarenakan berbagai data yang terkumpul kemungkinan menjadi kunci terhadap apa yang akan atau sudah diteliti. 


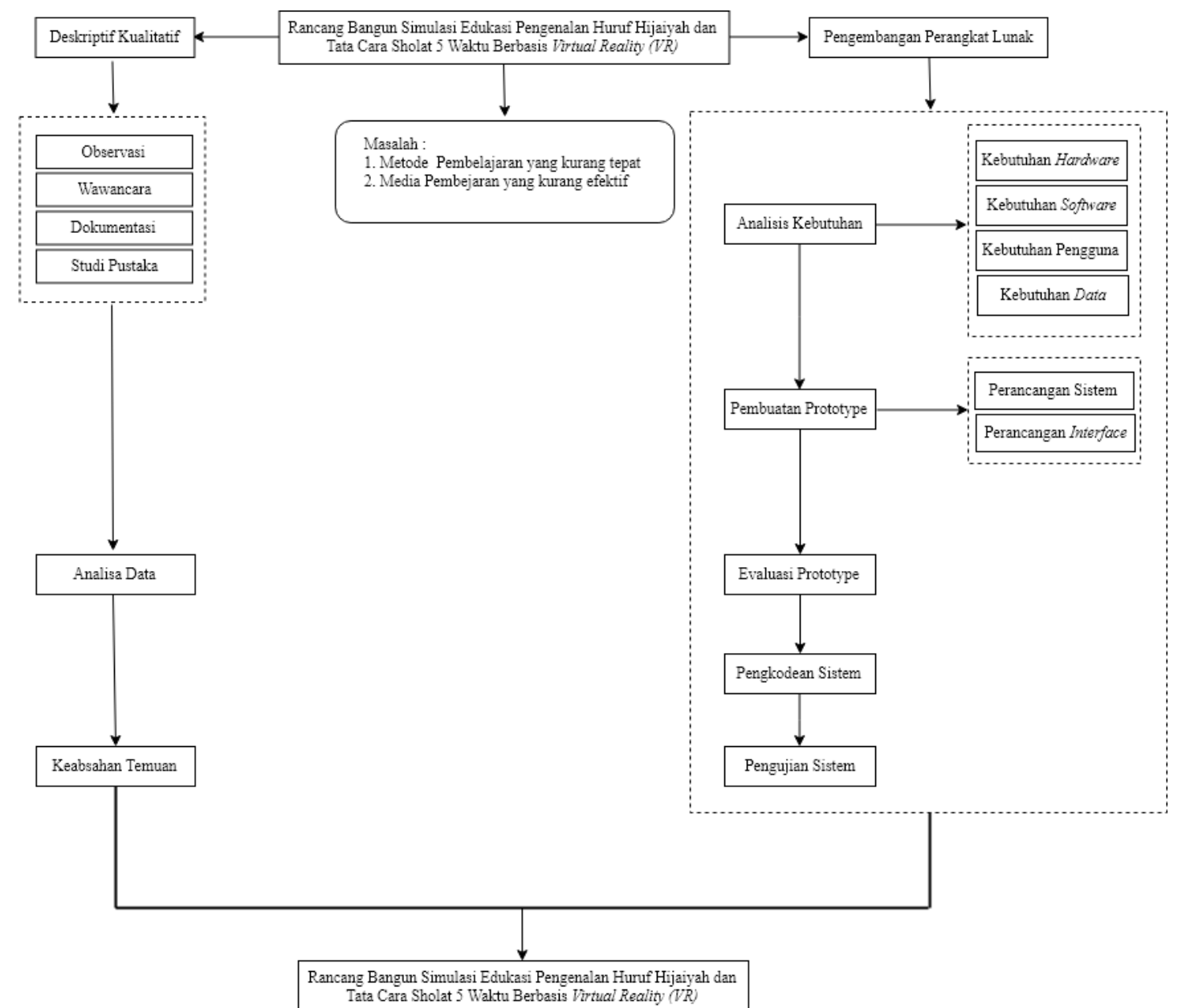

Gambar Alur Penelitian langkah-langkah yang dilakukan adalah dengan menggunakan empat metode yaitu observasi, wawancara, dokumentasi, dan studi pustaka.

\subsubsection{Metode Pengembangan Perangkat Lunak}

\begin{abstract}
Penelitian ini menggunakan metode pengembangan perangkat lunak Software Development Life Cycle (SDLC) dengan model Prototype. Prototype terdiri dari tujuh tahapan yaitu analisis kebutuhan, pembuatan prototype, evaluasi prototype, pengkodean sistem, pengujian sistem, evaluasi sistem, dan penggunaan sistem.

Penulis menggunakan metode ini, karena metode ini dirasa sangat cocok dengan aplikasi yang akan dibangun.

Dari ketujuh tahapan yang terdapat pada metode prototype diatas peneliti hanya menggunakan beberapa tahapan antara lain analisis kebutuhan pembuatan prototype, evaluasi prototype, pengkodean sistem dan pengujian sistem.
\end{abstract}

\section{a. Analisis Kebutuhan}

Pada tahapan ini dilakukan analisa kebutuhan dengan melakukan pengumpulan data dengan konsep deskriptif dan data kualitatif. Adapun b. Pembuatan Prototype

Setelah mendapatkan serta mengetahui seluruh kebutuhan yang diperlukan dalam melakukan pengembangan aplikasi, maka selanjutnya dilakukan pembuatan prototype. Tahap awal yaitu perancangan sistem menggunakan teknik UML. Kemudian tahap kedua yaitu melakukan perancangan data. Tahap yaitu terakhir perancangan interface.

c. Evaluasi Prototype

Evaluasi dilakukan dengan mengadakan diskusi dengan pihak SMP Negeri 2 Moyo Hulu. Diskusi yang dibicarakan mengenai kelayakan dan kesesuaian prototype yang telah dibuat. Kelayakan dan kesesuaian merupakan ketersediaan dan kelengkapan fungsi-fungsi yang terdapat pada prototype sudah sesuai dengan yang diinginkan pihak SMP Negeri 2 Moyo Hulu atau belum. Apabila prototype sudah sesuai, maka pengembangan selanjutnya yaitu menulis kode program untuk sistem yang akan digunakan. 
Dalam hal ini sistem yang digunakan adalah aplikasi android.

\section{d. Pengkodean Sistem}

Setelah prototype yang dibangun telah selesai kemudian dievaluasi, apabila telah sesuai dengan apa yang diteliti, maka akan dilakukan proses coding. Dalam tahapan ini pengkodean program menggunakan bahasa pemrograman C\#, dan Unity untuk membangun game.

e. Pengujian Sistem

Sistem yang telah selesai dibangun melalui tahap coding, kemudian dilakukan pengujian sistem. Hal ini dilakukan untuk memastikan bahwa perangkat lunak yang telah dibuat dapat digunakan dengan baik dan sudah layak pakai atau perlu disempurnakan lagi.

Dalam penelitian ini akan digunakan pengujian terhadap prototype dengan menggunakan metode pengujian Black-box testing memungkinkan

penguji perangkat lunak untuk melakukan serangkaian pengujian berdasarkan masukan (input) sesuai dengan kondisi tertentu yang akan mengerjakan tugas - tugas dari keseluruhan kebutuhan fungsi sebuah program.

\section{HASIL DAN PEMBAHASAN}

\subsection{Hasill Pengumpulan Data}

Adapun penerapan dari hasil metode prototype yang telah diterapkan sampai dengan pengujian sistem pada penelitian ini dibagi atas pembahasan hasil pengumpulan data, perancangan sistem dan pembangunan game edukasi yang telah dilakukan.

Hasil pengumpulan data pada penelitian ini adalah sebagai berikut :

1. Observasi

Hasil observasi yang telah diperoleh peneliti adalah sebagai berikut:

a. Data mata pelajaran pendidikan agama Islam.

b. Data materi pembelajaran pengenalan huruf hijaiyah dan tata cara sholat.

2. Wawancara

Dari hasil wawancara yang telah dilakukan peneliti dapat disimpulkan:

a. Mata pelajaran pendidikan agama Islam menggunakan kurikulum K13.

b. Mata pelajaran pendidikan agama Islam tentang sholat dan pengenalan huruf hijaiyah terdapat pada silabus kelas VII.

c. Metode pembelajaran yang digunakan yaitu menggunakan metode simulasi dan kerja kelompok, dengan harapan siswa dapat lebih memahami materi yang disampaikan. Ditambah dengan praktik.

d. Guru mata pelajaran pendidikan agama Islam menyampaikan materi dengan cara menjelaskan teori-teori yang berkaitan dengan materi yang sedang dipelajari menggunakan buku paket.

e. Siswa mendengarkan penjelasan dari guru mata pelajaran pendidikan agama Islam dan mencatat bagian-bagian penting yang nantinya akan diajadikan sebagai bahan praktik. Siswa maju satu persatu kedepan ketika disebutkan atau dipanggil namanya oleh guru pendidikan agama islam untuk mempraktikkan materi yang telah disampaikan didepan kelas. Sedangkan temanteman yang lainnya menyimak apa yang dipraktikkan oleh temannya.

3. Studi pustaka

Studi pustaka yang digunakan untuk untuk memperoleh data serta informasi dalam penelitian ini meliputi :

1. Silabus kelas VII bab 4, bab 9 dan bab 10 mata pelajaran pendidikan agama islam.

2. Buku paket mata pelajaran pendidikan agama islam kelas VII.

3. Rencana Pelaksanaan Pembelajaran (RPP) Bab 11 mata pelajaran pendidikan agama islam kelas VII.

4. Dokumentasi buku paket SMP kelas VII, yang dimana didalam buku paket tersebut terdapat materi yang berkaitan dengan tata cara sholat 5 waktu dan pengenalan huruf hijaiyah yaitu terdapat pada bab 4, 9 dan bab 10.

\subsection{Pembuatan Prototype}

Adapun tahapan dalam pembuatan prototype game edukasi tata cara sholat 5 waktu dan pengenalan huruf hijaiyah ini meliputi tahapan perancangan sistem menggunakan Unified Modelling Language (UML). UML merupakan rancangan dari struktur aplikasi yang akan dibangun yang terdiri dari Usecase Diagram, Class Diagram, Activity Diagram dan Sequence Diagram. Selanjutnya perancangan interface.

\section{Perancangan sistem}

Perancangan aplikasi game edukasi tata cara sholat 5 waktu dan pengenalan huruf hijaiyah di SMPN 2 Moyo Hulu meliputi :

A. Sistem yang diusulkan

Berdasarkan hasil wawancara yang dilakukan oleh peneliti pada SMPN 2 Moyo Hulu diketahui sistem yang diusulkan adalah Aplikasi Tata Cara Sholat 5 Waktu dan Pengenalan Huruf Hijaiyah sebagai media pembelajaran yang efektif. 
B. Use case Diagram

Use case diagram mendiskripsikan hubungan antara pengguna sistem (actor) dengan aktivitas-aktivitas proses pada game edukasi tata cara sholat 5 waktu dan pengenalan huruf hijaiyah. Pada game edukasi tata cara sholat 5 waktu dan pengenalan huruf hijaiyah ini hanya terdapat satu aktor yakni User. Untuk menjelaskan use case diagram dari Game Edukasi Tata Cara Sholat 5 Waktu dan Pengenalan Huruf Hijaiyah Berbasis Virtual Reality (VR) yang akan dibangun dijelaskan pada use case spesifikasi tiap aktor.

1. Use case diagram pengenalan huruf hijaiyah dan tata cara sholat 5 waktu.

Berikut ini merupakan use case diagram pengenalan huruf hijaiyah dan tata cara sholat 5 waktu. Use case diagram berikut menjelaskan interaksi aktor dengan aplikasi. Aktor masuk kedalam game dengan memililih menu utama, di dalam menu utama terdapat dua pilihan menu yaitu menu untuk pengenalan huruf hijaiyah dan menu untuk tata cara sholat 5 waktu. Ketika aktor memilih salah satu menu tersebut maka aktor langsung masuk ke dalam halaman menu yang telah dipilih. Seperti contohnya aktor memilih menu pengenalan huruf hijaiyah maka aktor langsung masuk ke halaman game pengenalan huruf hijaiyah.

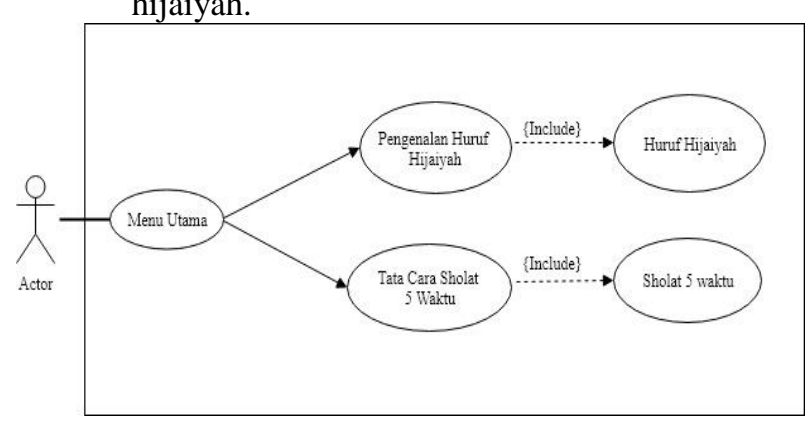

Gambar Usecase Diagram Pengenalan Huruf Hijaiyah

\section{Activity Diagram}

Activity Diagram Pengenalan Huruf Hijaiyah dan Tata Cara Sholat 5 Waktu.
Gambar dibawah ini adalah gambar activity diagram pengenalan huruf hijiyah dan tata cara sholat 5 waktu yang menjelaskan aktivitas yang berjalan ketika user mulai membuka game.

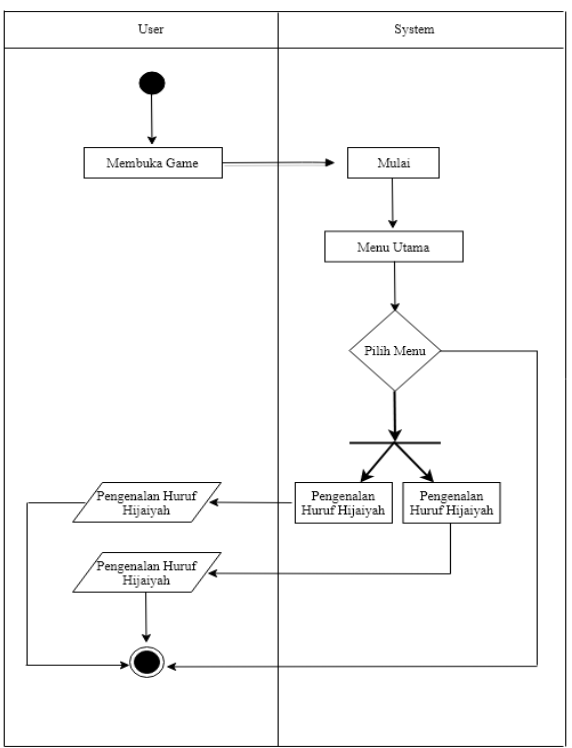

Gambar Activity Diagram Pengenalan Huruf Hijaiyah dan Tata Cara Sholat 5 Waktu

3. Sequence Diagram

Sequence Diagram Tata Cara Sholat 5 Waktu.

Sequence diagram menggambarkan kelakuan objek pada pada usecase dengan mendeskripsikan waktu hidup objek dan pesan yang dikirimkan dan diterima antar objek.

Berikut gambarannya:

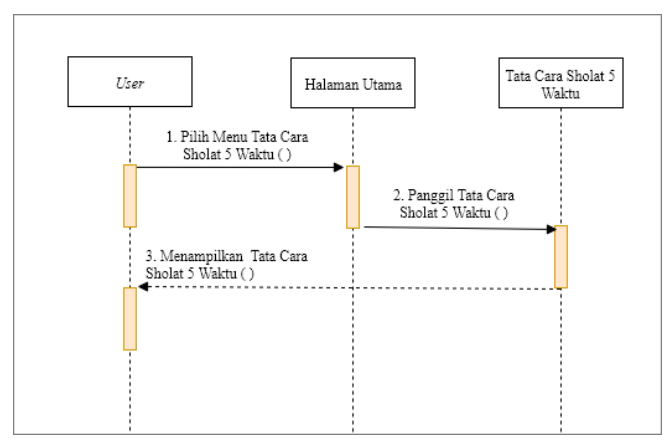

Gambar Sequence DiagramTata Cara Sholat 5 Waktu

3.1 Sequence Diagram Pengenalan Huruf Hijaiyah

Sequence diagram menggambarkan kelakuan objek pada use case dengan mendeskripsikan waktu hidup objek dan pesan yang dikirimkan dan diterima antar objek. 
Berikut gambarannya:

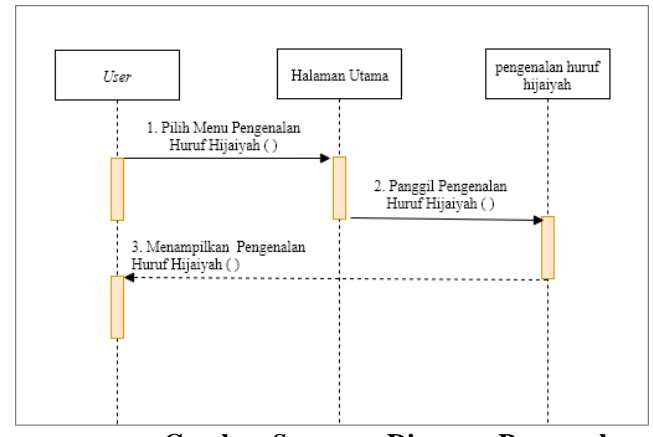

Gambar Sequence Diagram Pengenalan Huruf Hijaiyah

4. Class Diagram Pengenalan Huruf Hijaiyah dan Tata Cara Sholat 5 Waktu.

Pada class diagram mendiskripsikan jenis-jenis objek dalam aplikasi Pengenalan Huruf Hijaiyah dan Tata Cara Sholat 5 Waktu Berbasis Virtual Reality (VR). Class diagram juga menunjukkan operasi sebuah class dan batasan yang terdapat dalam hubungan dengan objek.

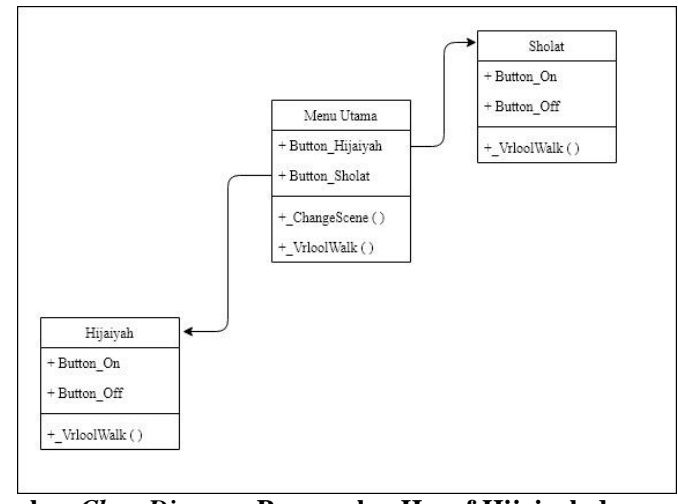

Gambar Class Diagram Pengenalan Huruf Hijaiyah dan Tata Cara Sholat 5 Waktu.

\subsubsection{Perancangan Interface}

Perancangan Interface User

Adapun rancangan tampilan user membuka game adalah sebagai berikut :

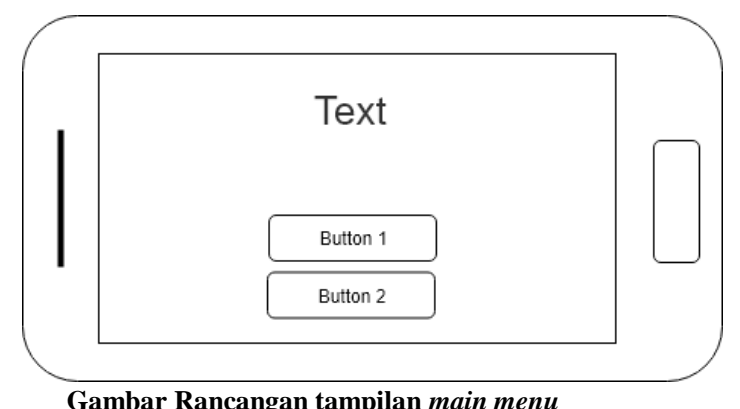

Gambar diatas merupakan rancangan tampilan saat user membuka game. Pada gambar diatas menampilkan main menu atau menu utama sebelum user memainkan game. Terdapat sebuah text, dua buah button yaitu button 1 dan button 2. Text disini adalah judul selamat datang di game. Button 1 yaitu pilihan materi untuk materi pengenalan huruf hijaiyah dan button 2 yaitu pilihan materi untuk materi tata cara sholat 5 waktu. Untuk memilih salah satu menu, user harus mengarahkan kursor berwarna merah ke salah satu materi game yang akan dimainkan.

A. Perancangan Interface Game Pengenalan Huruf Hijaiyah

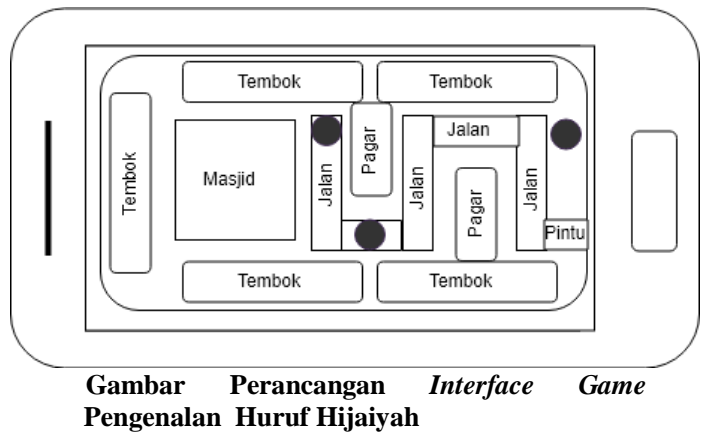

Gambar diatas menjelaskan tampilan interface arena game pengenalan huruf hijaiyah. Pada gambar diatas terdapat beberapa buah tembok dan pembatas antara jalan dan user untuk mencari huruf hijaiyah. Huruf hijaiyah ditandai dengan simbol lingkaran yang telah di acak dan ditempatkan dibeberapa titik. Tugas siswa adalah mencari huruf hijaiyah dengan menyusuri jalan dan masuk melalui pintu masuk yang telah dibuat.

B. Perancangan Interfae Game Tata Cara Sholat 5 Waktu

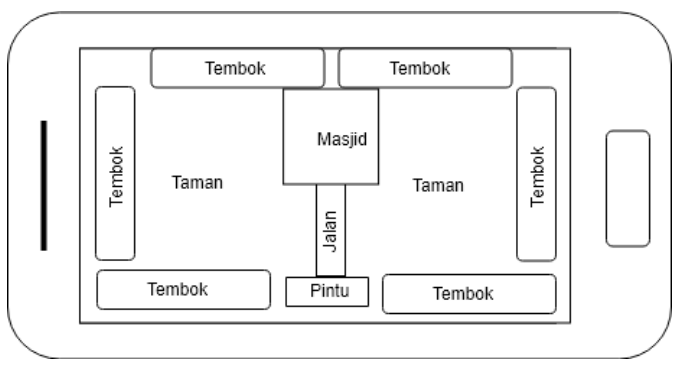

Gambar Perancangan Interface Tata Cara Sholat 5 Waktu

Gambar diatas menjelaskan tampilan interface arena game yang akan digunakan oleh user untuk belajar cara sholat. Gambar 3D telah dibuat untuk mempermudah user dalam belajar cara sholat. Tugas siswa 
adalah mempraktikkan gambar 3D yang telah disiapkan oleh penulis.

\subsection{Evaluasi Prototype}

Proses evaluasi rancangan prototype Game Edukasi Tata Cara sholat 5 Waktu dan Pengenalan Huruf Hijaiyah Berbasis Virtual Reality $(V R)$. Untuk mengetahui fitur-fitur apa saja yang terdapat pada game edukasi, agar nyaman digunakan saat praktik oleh siswa dan mudah dalam melakukan penilaian oleh guru mata pelajaran pendidikan agama islam.

Berikut tabel perbandingan prototype 1 dan prototype 2:

\begin{tabular}{|l|c|}
\hline \begin{tabular}{|l|} 
Hasil Evaluasi \\
Prototype 1
\end{tabular} & $\begin{array}{c}\text { Hasil Evaluasi } \\
\text { Prototype 2 }\end{array}$ \\
\hline a. Belum ada main \\
menu & Sesuai \\
pembuka & game \\
saat user mulai & \\
memainkan & \\
game dan bisa & \\
langsung & \\
memilih & \\
kategori game & \\
yang ingin & \\
dimainkan oleh & \\
user. & \\
b. Gambar objek \\
pada kategori \\
game Tata Cara \\
Sholat 5 Waktu \\
masih berbentuk \\
gambar 2D. \\
c. Gambar objek \\
pada kategori \\
game \\
Pengenalan \\
Huruf Hijaiyah \\
masih berbentuk \\
gambar 2D. \\
\hline
\end{tabular}

\subsection{Implementasi}

a. Implementasi Halaman Main menu / Menu utama

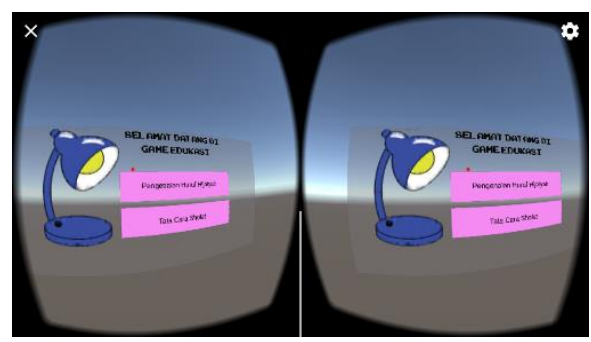

Gambar Implementasi Halaman Menu Utama

Gambar diatas adalah gambar halaman main menu sebelum siswa memainkan game. Pada gambar diatas terdapat dua menu pilihan untuk siswa yaitu menu untuk game pengenalan huruf hijaiyah dan menu untuk tata cara sholat.

b. Implementasi Game Pengenalan Huruf Hijaiyah

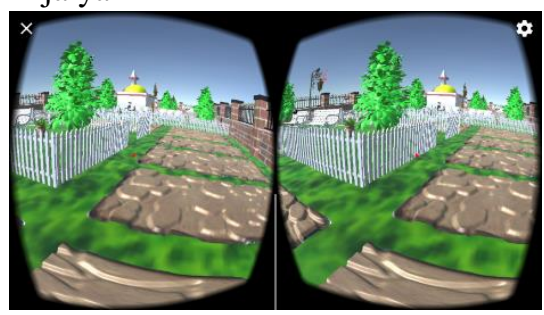

Gambar Implementasi Halaman Menu Utama Gambar diatas adalah gambar implementasi game pengenalan huruf hijaiyah dan merupakan detail arena tempat siswa mencari huruf-huruf hijaiyah. Siswa akan berjalan menuju huruf hijaiyah dengan menggunakan kacamata Virtual Reality $(V R)$, jika siswa telah menemukan huruf hijaiyah maka siswa harus menyebutkan nama hurufnya.

c. Implementasi detail huruf hijaiyah

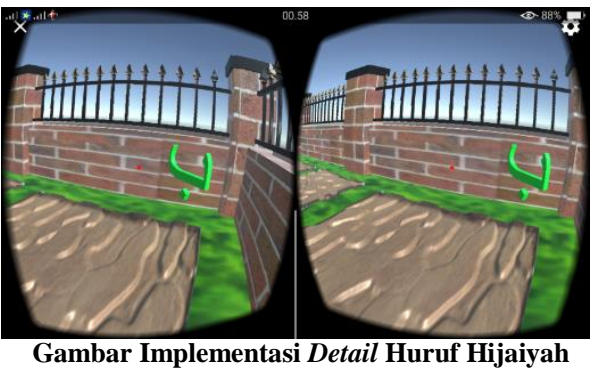

Gambar diatas merupakan detail huruf hijaiyah berbentuk 3 dimensi, agar mudah di baca dan dikenali oleh siswa. Ada 30 huruf hijaiyah yang telah di masukkan ke dalam aplikasi game pengenalan huruf hijaiyah oleh penulis. Huruf hijaiyah itulah yangnanti akan di cari oleh siswa 
dan berwarna warni sehingga ada tantangan untuk siswa dalam mencari huruf hijaiyah.

\section{d. Implementasi Game Tata Cara Sholat 5 Waktu}

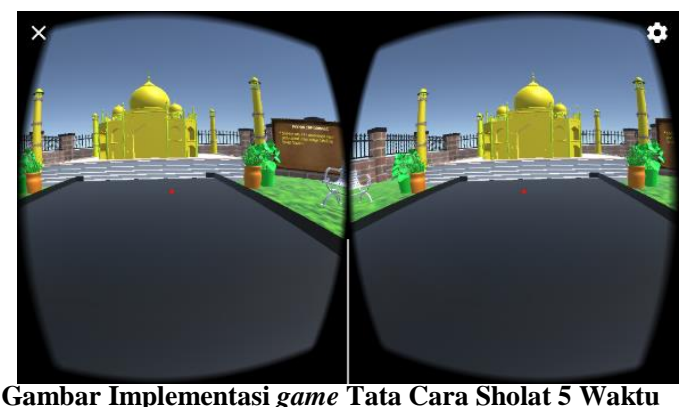

Gambar diatas merupakan detail game Tata Cara Sholat 5 Waktu. Pada gambar diatas terdapat gambar masjid dan papan informasi untuk menginformasikan kepada siswa tentang definisi game Tata Cara Sholat 5 Waktu. Didalam masjid terdapat beberapa objek yang mempraktikkan Tata Cara Sholat 5 Waktu.

\section{e. Implementasi detail objek Tata Cara Sholat 5}

Waktu

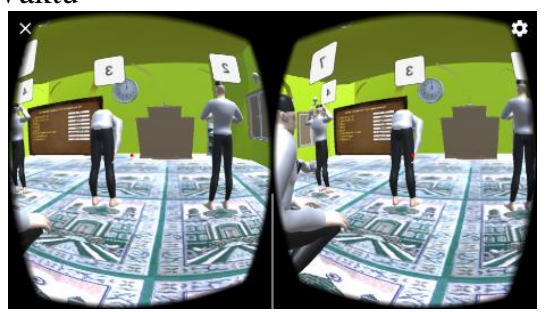

Gambar Implementasi detail objek Tata Cara Sholat 5 Waktu

Gambar diatas merupakan gambar objek yang akan dilihat oleh siswa untuk diikuti dan dipraktikkan oleh siswa. Pada game tata cara sholat 5 waktu ini, hanya menjelaskan satu waktu sholat yaitu sholat magrib. Karena do'a yang digunakan pada setiap sholat hanya berbeda saat melafazkan niat dan jumlah rakaat. Sedangkan do'a yang baca sama pada setiap sholat. Terdapat papan informasi untuk melihat do'a tiap-tiap gerakan sholat. Siswa berjalan menuju objek dengan cara menundukkan kepala secara perlahan agar dapat mendekat ke objek.

\section{KESIMPULAN DAN SARAN}

\subsection{Kesimpulan}

Dari hasil analisis dan perancangan sistem yang telah dilakukan sebelumnya maka penulis dapat mengambil kesimpulan bahwa Game Edukasi Tata Cara Sholat 5 Waktu dan Pengenalan Huruf Hijaiyah berhasil dibuat dengan menggunakan bahasa pemrograman C\# (C Sharp), photoshop dan blender untuk membuat gambar dan objek 3D. Adapun fitur yang terdapat pada Game Edukasi Tata Cara Sholat 5 Waktu dan Pengenalan Huruf Hijaiyah yaitu fitur huruf hijaiyah dan objek 3D, menggunakan teknologi Virtual Reality (VR) yang dibantu dengan kacamata Google Cardboard. Dengan beberapa fitur dan teknologi yang digunakan maka game ini bisa menjadi media pembelajaran bagi anak-anak siswa SMP.

\subsection{Saran}

Dari hasil pembuatan Game Edukasi Tata Cara Sholat 5 Waktu dan Pengenalan Huruf Hijaiyah Berbasis Virtual Reality (VR), penulis memberikan saran agar pada tahap selanjutnya dilakukan pengembangan sistem antara lain meliputi:

1. Penambahan sound pada huruf hijaiyah, sehingga dapat digunakan oleh siswa secara massal, tidak hanya digunakan oleh orang yang berstatus siswa saja serta penambahan fitur sholat jamak dan sholat qashar.Penambahan fitur skor pada game agar dapat mengetahui tingkat pemahaman saat dimainkan.

2. Penambahan fitur skor pada game agar dapat mengetahui tingkat pemahaman saat dimainkan.

3. Penambahan fitur level atau peningkatan level agar dapat lebih mengasah kemampuan siswa yaitu seperti fitur cara baca atau makhrojul huruf dan hukum bacaan serta fitur belajar iqro dari juz 1 sampai juz 3.

\section{DAFTAR PUSTAKA}

[1] Abdelhameed, W. A. (2013). Virtual Reality Use in Architectural Design Studios: A case of studying structure and construction. International Conference on Virtual and Augmented Reality in Education.

[2] Anderson EF. McLoughlin L, Liarokapis F, Peters C, Petridis P, de Freitas S (2010) Developingserious games for cultural heritage: a state-of-the-art review. Virtual Reality 14:255275.

[3] Agusyanto, R. (2007). Jaringan sosial dalam organisasi. PT. Raja Grafindo Persada,. Jakarta.

[4] A O'Brien, James, (2005). Pengatur Sistem Informasi Perspektif Bisnis dan Manajerial. Salemba Empat, Jakarta. 
[5] Arif S. Sadiman, (2006). Media pendidikan: Pengertian, pengembangan dan pemanfaatannya. PT Raja Grafindo Persada, Jakarta.

[6] Dermawan Wibisono. 2006. Manajemen Kinerja, Konsep, Desain, dan Teknik Meningkatkan Daya Saing Perusahaan. Erlangga. Jakarta.
[7] Fajarianto, Otto. (2016). "Prototype Pelayanan Akademik Terhadap Komplain Mahasiswa Berbasis Android". Jurnal Lentera ICT. Vol. 3 No. 1 Hal. 55. Tanggal Akses: 6 April 2018.

[8] Flavell, Lance, 2010. Beginning Blender: Open Source $3 D \quad$ Modeling, Animation, and Game Design. Apress .Paul, Manning. 